九州大学学術情報リポジトリ

Kyushu University Institutional Repository

\title{
Development of multilayer imprint process for solid oxide fuel cells
}

Tokumaru, Kazuki

Department of Mechanical Engineering, Graduate School of Kyushu University

Tsumori, Fujio

Department of Mechanical Engineering, Kyushu University

Kudo, Kentaro

Department of Mechanical Engineering, Graduate School of Kyushu University

Osada, Toshiko

Department of Mechanical Engineering, Kyushu University

他

http://hdl. handle. net/2324/1916278

出版情報: Japanese Journal of Applied Physics. 56 (6S1)，pp.06GL04-1-06GL04-4，2017-05-30. 公 益社団法人応用物理学会

バージョン：

権利関係 : 


\section{Development of multi-layer imprint process for solid oxide fuel cells}

Kazuki Tokumaru ${ }^{1}$, Fujio Tsumori ${ }^{2 *}$, Kentaro Kudo $^{1}$, Toshiko Osada ${ }^{2}$, Kazunari Shinagawa $^{2}$ ${ }^{1}$ Dept. of Mechanical Engineering, Graduate School of Kyushu University, Fukuoka, Japan ${ }^{2}$ Dept. of Mechanical Engineering, Kyushu University, Fukuoka, 819-0395, Japan

E-mail: tsumori@mech.kyushu-u.ac.jp

Solid oxide fuel cells (SOFC) are fuel cells made of ceramics. To enhance the energy density of SOFC, we developed a SOFC with wave-electrolyte layer. As a wavy electrolyte has larger reacting area than a flat-electrolyte, higher energy density could be obtained. Our proposed process is named micro powder imprint $(\mu \mathrm{PI})$ with multi-layer imprint process that is useful to fabricate micro scale pattern on a ceramic sheet such as an electrolyte layer of SOFC. The $\mu \mathrm{PI}$ is inspired by nano imprint lithography, therefore it also possesses the same advantages of high resolution and mass productivity. The starting material for $\mu \mathrm{PI}$ is a compound sheet containing material ceramic powder and binder consisting of thermoplastic resin. In this paper, 2 different sheets were stacked into one sheet as a multi-layer sheet for the $\mu$ PI process to form a wave-type compound sheet. As the initial state of the stacked sheet, such as thickness or mechanical properties of each layer, affects the final wavy shape, we changed the initial thickness and the material composition. As a result, the SOFC unit cell with wavy-electrolyte was fabricated. It is noted that the anode layer was formed at the same time. After adding the cathode layer, we succeeded to prepare a complete cell for testing power generating. 


\section{Introduction}

Solid oxide fuel cells (SOFC) have the highest efficiency among various kinds of fuel cells. They are mainly used for relatively large scale power source such as power plants. SOFC is composed of anode, electrolyte and cathode, which are all ceramic materials ${ }^{1-5)}$. SOFC is expected to be a new main generator; however energy density is not high and downsizing is also required to be more popular.

There have been number of reports that targeted downsizing ${ }^{6-10)}$. Improvement of SOFC by the optimized interface structure of electrodes and electrolyte have been reported by $\mathrm{H}$. Iwai ${ }^{11-13)}$. Today, yttria-stabilized zirconia (YSZ) sheet with thickness of under $100 \mu \mathrm{m}$ is widely used for the electrolyte. In Iwai's reports, a wavy-electrolyte layer was evaluated to improve the reaction efficiency by expansion of the surface area of the sheet and to maximize current density by decreasing movement resistance of oxygen ion. In these paper, computational simulation was performed, as the YSZ is fragile and difficult to be machined.

We propose a new method to form a wavy electrolyte layer in this work. The aim of our study is to develop a processing method of the thin and wavy YSZ electrolyte for SOFC. We will introduce advanced process based on micro powder imprint $(\mu \mathrm{PI})^{14-20)}$ in this paper. $\mu \mathrm{PI}$ is a combined process of nano imprint lithography (NIL) ${ }^{21)}$ and powder metallurgy. NIL is a process to transcribe a nano-pattern on a resin film using a mold, and has been proposed by S. Y. Chou ${ }^{21)}$. The process can produce a fine pattern on the surface in high resolution, and is mass-productive. NIL is a process for polymer as a work material, while $\mu \mathrm{PI}$ is a process to process inorganic materials. In $\mu \mathrm{PI}$, starting material is a compound sheet containing powder of inorganic materials and resin as a binder. Fine pattern can be transcribed on a compound sheet by pressing with a mold as similarly with NIL. After imprinting, the resin in the compound is decomposed by heating, and inorganic powder is bonded together during the following sintering step.

Authors already have reported fabrication of electrolyte sheet which has micro pattern on one side of the sheet by $\mu \mathrm{PI}{ }^{14-18)}$. In this study, manufacturing process of the wavy electrolyte is proposed. Figure 1 is the flow of manufacturing process of a unit cell for SOFC. First, we prepared compound sheets for anode and electrolyte by tape casting. Anode and electrolyte sheets were laminated to be worked. Second process is imprinting. In this pressing process, by using layer sheet, a micro pattern is transcribed not only on one side of the electrolyte sheet but also the other surface. Next, debinding and sintering process are performed as the third process. By controlling a heating program, a wave-type sintered YSZ sheet without defects could be obtained. Finally, cathode slurry is applied and sintered. Detail of the 
process will be explained in the following section.

\section{Experimental methods}

Anode and electrolyte compound sheets were fabricated by tape casting ${ }^{22-25)}$. At first, slurry containing a material powder and binder was prepared with water solvent, and the slurry was applied onto substrate. After drying, a compound sheet was obtained. In this paper, YSZ powder (TZ-8Y, Tosoh Corp.) and NiO powder were prepared for electrolyte and anode parts. The component of binder was poly-vinyl-alcohol (degree of polymerization 500) and glycerin which was used as plasticizer to control formability of the compound. The particle size of the YSZ powder was about $100 \mathrm{~nm}$ and that of $\mathrm{NiO}$ was about $1 \mu \mathrm{m}$. Material powders were mixed with PVA, glycerin and water using a stirring deaerator (SK-350T, SHASHIN KAGAKU Co., LTD.). The ratio of powder and binder in the final compound sheet was controlled to be 50:50 in volume.

After stirring, the slurry was formed into a sheet by a table coater. The applied slurry was heated for drying out water by an oven at $50{ }^{\circ} \mathrm{C}$ for $300 \mathrm{~s}$. We prepared electrolyte sheets which contained only YSZ, and anode sheets with mixture of $\mathrm{NiO}$ and $\mathrm{YSZ}$ in the equal ratio. The thickness of the electrolyte compound sheet was $50 \mu \mathrm{m}$ and anode sheet was $100 \mu \mathrm{m}$. These two sheets were stacked and pressed into a sheet, and this 2-stacked-layer was imprinted by the same line-and-space patterned mold. The mold was made of polyimide sheets which was formed by a laser machining system. As polyimide is heat-resistant material which is available at a temperature over $200{ }^{\circ} \mathrm{C}$, so that it can be used as a material for the mold of imprinting. The pattern of the prepared mold was roundish triangular line and space. Figure 2 shows the cross section of the mold. The depth of valley was $70 \mu \mathrm{m}$ and the pitch of line was $135 \mu \mathrm{m}$. Imprinting was performed by servo press machine (DT-J330, Micro Fabrication Laboratory, LLC.) with heater attached on the press stage. Imprinting depth was precisely controlled by the servo press machine. Mold and layered compound sheet were stacked and were put in metallic container to prevent from flowing out of the compound material. The imprinting temperature was set to $125^{\circ} \mathrm{C}$ which is higher than the softening point of compound sheet. The press keeping time was $60 \mathrm{~s}$.

After sheet samples were formed, binder was removed and samples were sintered using an electric furnace in air atmosphere. While debinding and sintering, layer sheet bends under the influence of heat ${ }^{26)}$. In the heating process, compound sheets shrink by the decomposition of binder and sintering of powders. The shrinkage ratio of compound sheets is depending on the component, and sometimes the difference of this shrinkage between 
layer sheets would cause the bend and fracture of ceramic product. To prevent a warpage, the compound sheet was put between Yttria plates. During debinding process, organic materials were decomposed into gas materials, which could cause high inner pressure in the compact to break up the sample. To prevent the rapid gas formation, temperature program was considered using thermos gravimetric analysis (TGA). Figure 3 shows the result of TGA. Glycerin and PVA began to decompose at $200{ }^{\circ} \mathrm{C}$ and $300{ }^{\circ} \mathrm{C}$, respectively, and both of them were completely removed at $600{ }^{\circ} \mathrm{C}$. From this result, we set keeping temperatures at $200{ }^{\circ} \mathrm{C}$, $350{ }^{\circ} \mathrm{C}$, and $600{ }^{\circ} \mathrm{C}$ each for 3 hours in debinding process. The rate of temperature increase in debinding was set to $50^{\circ} \mathrm{C} / \mathrm{h}$. YSZ and $\mathrm{NiO}$ powder was sintered after debinding. YSZ is sintered at over $1300{ }^{\circ} \mathrm{C}$ and $\mathrm{NiO}$ is over $1200{ }^{\circ} \mathrm{C}$ in general. ${ }^{27-29)} \mathrm{We}$ set the sintering temperature $1400{ }^{\circ} \mathrm{C}$ and the keeping time 2 hours. The rate of temperature increase in sintering was $100^{\circ} \mathrm{C} / \mathrm{h}$.

The cathode layer was fabricated onto the sintered electrolyte layer. ${ }^{30)}$ The material of cathode was $\mathrm{LaSrMnO}_{3}$ (LSM). The LSM powder dispersed in isopropanol was applied on the surface of wavy electrolyte layer and sintered at $1100{ }^{\circ} \mathrm{C}$ for 2 hours.

\section{Results and discussion}

\section{1 two-layer Imprinting}

To analyze formability of compound sheets, we changed each compounding ratio of binder contained in the electrolyte sheet and the anode sheet. Table I shows each compounding ratio of electrolyte sheets and anode sheets. Because glycerin acts as plasticizer, sheets would become softer as the amount of glycerin increases. We prepared two kinds of sheets for electrolyte and anode, the thickness of which was $30 \mu \mathrm{m}$ and $300 \mu \mathrm{m}$, respectively. In laminating process, compound sheets were pressed by a flat plate set in container. We set the laminating pressure at $12.5 \mathrm{MPa}$ and the laminating temperature at $100{ }^{\circ} \mathrm{C}$. All compound sheets were bonded with each due to the adhesively of the binder at the temperature. In imprinting process, we set the imprinting pressure at $17.5 \mathrm{MPa}$ and the imprinting temperature at $125^{\circ} \mathrm{C}$. Both layered-sheets were imprinted in each condition.

Figure 4 shows cross sections of layer-sheets after imprinting with changing compounding ratio. Sample (a) made of electrolyte (A). Sample (b) made of electrolyte (B). Table II shows the dimension of each parts schematically shown in Fig. 2. In both samples, the depth of the pattern of the upper side, or mold side, was about $65 \mu \mathrm{m}$ and lower than the depth of mold by $5 \mu \mathrm{m}$. This is due to spring back of the formed sheets or elastic deformation of the polymer mold. In electrolyte layer, there are thick sections and thin sections. Sample (a) has the 
smaller gap in thickness between the thickest section and the thinnest section in electrolyte layer and the largest amplitude of the interface between electrolyte layer and anode layer. The gap between thickest section and thinnest section is larger as the electrolyte sheet is softer. This gap is caused by flow of electrolyte layer. During the imprint process, the thinnest section of electrolyte sheet was pressed from mold at first, and powder and binder flowed sideways, i.e. the valleys of the mold. As flowability become larger, the thinnest section be thinner and thickest section be thicker, and the gap become larger. The flowability of compound sheets was depend on the amount of glycerin. Electrolyte (B) has larger flowability than electrolyte (A), so sample (a) had smaller gap than that of sample (b). The gap in thickness of electrolyte would cause uneven permeation of oxygen ion, and a lowering of generating efficiency of SOFC. From the result of imprinting test, harder upper layer is fitted for fabricating wavy pattern by two-layer imprinting.

\subsection{Fabricating unit cell for SOFC}

Figure 5 shows appearance (a) and cross section (b) of an example of a fabricated unit cell for SOFC. The diameter of the cell was $13 \mathrm{~mm}$ and the power generation part was $8 \mathrm{~mm}$. Layer sheet was sintered without any cracking and bending by weight of yttria plate. The sample cell was put a work under hydrogen leak test using gas chromatography and we confirmed electrolyte layer has enough densely to prevent the leak of hydrogen.

From result of image processing, the area of interfaces between cathode and electrolyte was increased to $147 \%$ and between electrolyte and anode was increased to $122 \%$ from flat electrolyte. Hydrogen and oxygen ion react at the interface between electrolyte and anode, so the area of interfaces between electrolyte and anode will have more influence on power generation. The shape of interfaces between cathode and electrolyte can be designed and formed easily because the patterns of mold were transferred directly. However, the shape of interfaces between electrolyte and anode were influenced by the formability of compound sheets and imprinting conditions. To fabricate wavy electrolyte with even thickness, the control of manufacturing process is important, and we will try further improvement.

\section{Conclusions}

A thin and wavy electrolyte was fabricated by improved $\mu$ PI process with two-layer imprinting. Wave patterns can be changed by controlling compounding ratio of sheets. The unit cell did not have any crack and would be available as SOFC test cell. The interfaces 
between electrolyte and anode was increased to $122 \%$ from flat sheet. This means a reaction surface area increased and higher efficiency would be expected by the present process. Performance test of SOFC is our next work.

\section{Acknowledgments}

The authors would like to thank Pro. Hiroshige Matsumoto and Mr. Maeda for their help in hydrogen leak test. The authors would like to thank the following financial supports: JSPS KAKENHI Grant Number 15H04161, and JST A-STEP program Grant Number AS262Z01235L. 


\section{References}

1) E. I-Tiffee, A. Weber, D. Herbstritt, Journal of the European Ceramic Society, 21 (2001) P. 1805.

2) A. Weber, E. I-Tiffee, Journal of Power Sources, 127 (2004) P. 273.

3) S. P. S. Badwal, K. Foger, Ceramics International, 22 (1996) P. 257.

4) A. B. Stambouli, E. Traversa, Renewable and Sustainable Energy Reviews, 6 (2002) P. 433.

5) A. Kirubakaran, S. Jain, R.K. Nema, Renewable and Sustainable Energy Reviews, 13 (2009) P. 2430.

6) A. Faes, Aicha H-Wyser, A. Zryd, J. V. Herle, Membranes, 2 (2012) P. 585.

7) L. Holzer, B. Iwanschitz, Th, Hocker, B. Munch, M. Prestat, D. Wiedenmann, U. Vogt, P. Holtappels, J. Sfeir, A. Mai, Th, Graule, Journal of Power Sources, 196 (2011) P. 1279.

8) B. C. H. Steele, Solid State Ionics, 129 (2000) P. 95.

9) J. Will, A. Mitterdorfer, C. Kleinlogel, D. Perednis, L. J. Gauckler, Solid State Ionics, 131 (2000) P. 79.

10) K. Huang, ECS Transactions 12 (2008) P. 375.

11) A. Konno, H. Iwai, K. Inuyama, A. Kuroyanagi, M. Saito, H. Yoshida, K. Kodani, K. Yoshikata, Journal of Power Sources, 196 (2011) P. 98.

12) H. Iwai, A. Kuroyanagi, M. Saito, A. Konno, H. Yoshida, T. Yamada, S. Nishiwaki, Journal of Power Sources, 196 (2011) P. 3485.

13) A. Konno, H. Iwai, M. Saito, H. Yoshida, Journal of Power Sources, 196 (2011) P. 7442.

14) Y. Xu, F. Tsumori, H. Kang, H. Miura, J. Jpn. Soc. Powder Powder Metallurgy, 58 (2011) P. 673.

15) Y. Xu, F. Tsumori, H. Kang, H. Miura, Advanced Science Letters, 12 (2012) P. 170.

16) Y. Xu, F. Tsumori, T. Osada, H. Miura, Micro Nano Lett., 8 (2013) P. 571.

17) Y. Xu, F. Tsumori, T. Toyooka, H. Kotera, H. Miura, Jpn. J. Appl. Phys., 50 (2011) P. $06 \mathrm{GK} 11$

18) F. Tsumori, Y. Xu, H. Kang, T. Osada, H. Miura, Proc. Computational Plasticity XII, (2013) P. 1267

19) F. Tsumori, S. Hashimoto, M. Takahashi, Y. Xu, H. Kang, T. Osada, H. Miura, Proc. Powder Metallurgy World Congress, (2013) P-T6-72.

20) F. Tsumori, S. Hunt, T, Osada, H, Miura, Japanese Journal of Applied Physics, (2015).

21) S. Y. Chou, PR. Krauss, PJ. Renstrom, 14 (6) (1996) P. 4129. 
22) R. F-Gonzáles, T. Molina, S. Savvin, R. Moreno, A. Makradi, P. Núñez, Ceramics International, 40 (2014) P. 14253.

23) I. A. Aksay, Forming of Ceramics. Advances in Ceramics, 9 (1983) P. 94.

24) F. F. Lange, Journal of the American Ceramics Society, 72 (1989) P. 3.

25) K. P. Plucknett, C. H. Carlos, C. Hughes, D. S. Wilkinson, Journal of the American Ceramics Society, 77 (1994) P. 2145.

26) Y. M. Shabana, H. A. Bruck, M. L. Pines, J. G. Kruft, International Journal of Solids and Structures, 43 (2006) P. 7852.

27) I.-Wei Chen, X.-H. Wang, Nature, 404 (2000) P. 168.

28) C. L-Robert, F. Ansart, C. Deloget, M. Gaudon, Ceramics International 29 (2003) P. 151.

29) K. Matsui, Tosoh Research \& Technology, 55 (2011) P. 7.

30) H. Matsumoto, I. Nomura, S. Okada, T, Ishihara, Solid State Ionics, 179 (2008) P. 1486. 


\section{Figure Captions}

Fig. 1. (Color online) Flow of manufacturing process of unit cell for SOFC.

Fig. 2. (Color online) Cross sectional view of the mold.

Fig. 3. (Color online) Result of TGA for PVA and glycerin.

Fig. 4. (Color online) Cross sectional view of imprinted layer sheets. Sample (a) made of electrolyte (A), and sample (b) made of electrolyte (B).

Fig. 5. (Color online) Sample photo (a) and cross section of unit cell for SOFC (b). 
Table I. Composition of electrolyte and anode sheets.

\begin{tabular}{ccccc}
\hline vol \% & YSZ & NiO & PVA & Glycerin \\
\hline Electrolyte (A) & 50 & - & 40 & 10 \\
Electrolyte (B) & 50 & - & 35 & 15 \\
Anode & 25 & 25 & 30 & 20 \\
\hline
\end{tabular}


Table II. Dimension of each parts shown in Fig. 4.

\begin{tabular}{cccc}
\hline$\mu \mathrm{m}$ & (1) Thickest section & (2) Thinnest section & (3) Amplitude \\
\hline Sample (a) & 31.6 & 15.5 & 50.6 \\
Sample (b) & 36.6 & 11.8 & 37.6 \\
\hline
\end{tabular}




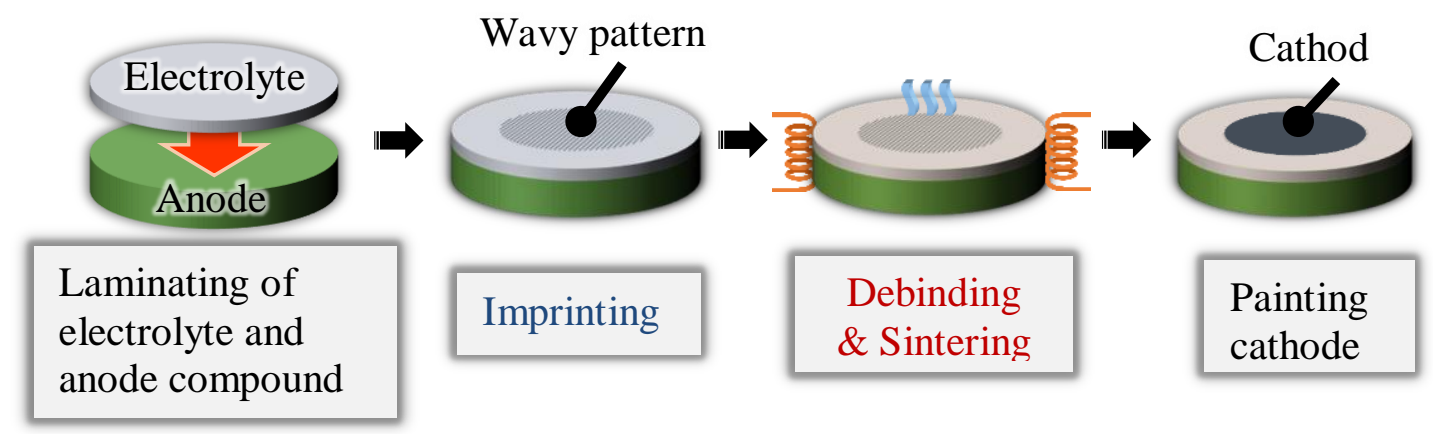

Fig. 1. (Color online) 


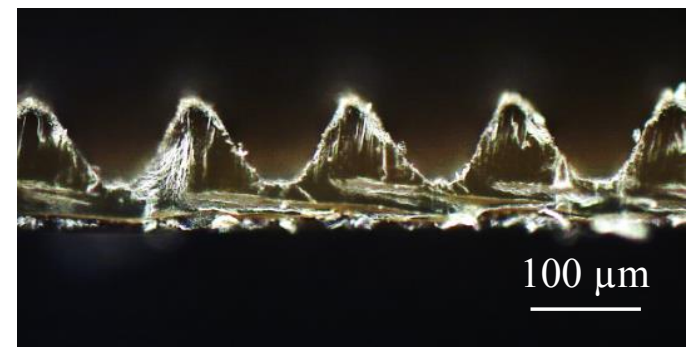

Fig. 2. (Color online) 


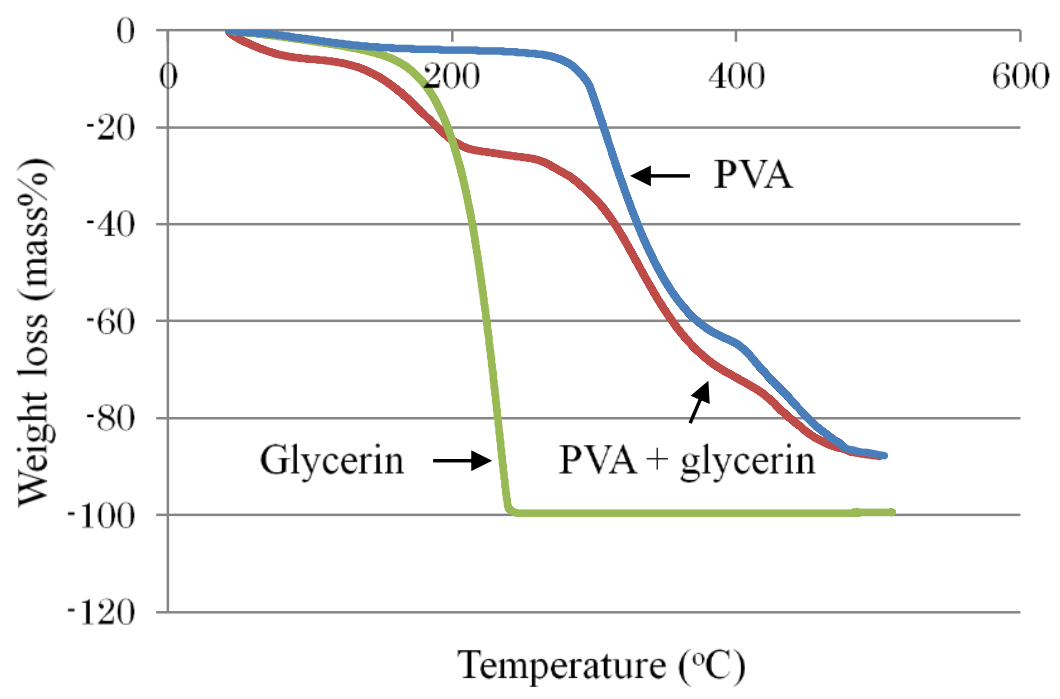

Fig. 3. (Color online) 
$100 \mu \mathrm{m}$
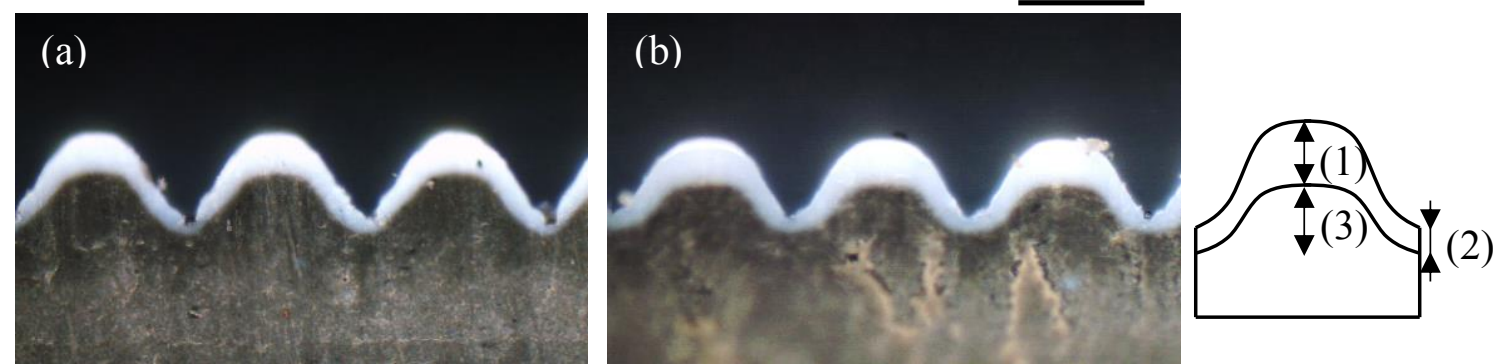

Fig. 4. (Color online) 


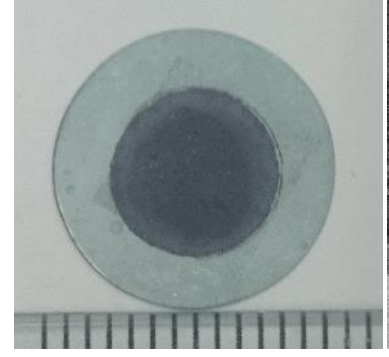

(a)

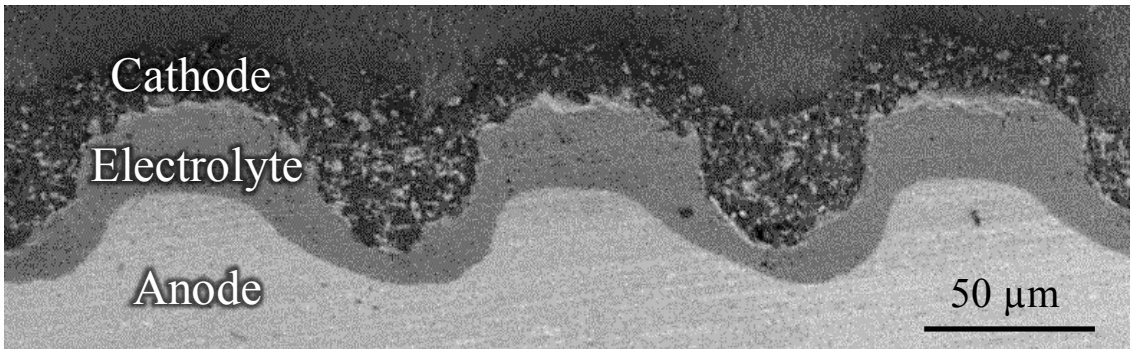

(b)

Fig. 5. (Color online) 